McKee, R. W. (195I). In Biochemistry and Physiology of Protozoa. Vol. I, p. 25 I. [A. Lwoff, editor.] New York: Academic Press Inc.

Otto, G. F., Jeske, H. A., Frost, D. V. \& Perdue, H. S. (1957). Poult. Sci. 36, I147.

Pratt, I. (1940). Trans. Amer. micr. Soc. 59, 31 .

Pratt, I. (194I). Amer. F. Hyg. 34, Sect. C, p. 54.

Rogers, E. F., Clark, R. L., Pessolano, A. A., Becker, H. J., Leanza, W. J., Sarett, L. H., Cuckler, A. C., McManus, E., Garzillo, M., Malanga, C., Ott, W. H., Dickinson, A. M. \& Van Iderstine, A. (r960). 7. Amer. chem. Soc. 82, 2974.

Rollo, I. M. (1955). Brit. F. Pharmacol. ro, 208.

Schildt, C. S. \& Herrick, C. A. (1955). F. Parasit. 41, Suppl. p. 18.

Stephens, J. F. \& Tugwell, R. L. (1959). Poult, Sci. 38, I 249.

Stephens, J. F. \& Tugwell, R. L. (1960). Poult. Sci. 39, I 183.

Stephens, J. F., Tugwell, R. L. \& Harms, R. H. (1957). Poult. Sci. 36, I 59.

Taylor, A. E. R. (1957). Trans. R. Soc. trop. Med. Hyg. 51, 24 I.

Tugwell, R. L., Stephens, J. F. \& Harms, R. H. (1957). Poult. Sci. 36, 1245.

Tyzzer, E. E. (1929). Amer. F. Hyg. Io, 269.

Waletzky, E. \& Hughes, C. O. (1946). Amer. F. vet. Res. 7, 365.

Woods, D. D. (1940). Brit. F. exp. Path. 21, 74.

\title{
The effect of milk intake on nematode infestation of the lamb
}

\author{
By C. R. W. Spedding, T. H. Brown and R. V. Large, The Grassland Research \\ Institute, Hurley, Berks
}

It is well known that nematodes inhabiting the alimentary tract may reduce the growth rate of lambs (Kauzal, r 936; Andrews, Kauffman \& Davis, I944; Franklin, Gordon \& Macgregor, 1946; Taylor, r942, 1953; Spedding, 1953, 1955; Spedding $\&$ Brown, I957a,b,c). This effect is due in part to reduction of food intake (Gordon, 1950; Gibson, 195 I, 1955; Spedding, 1954) and to interference with the digestive economy of the sheep (Stewart, 1932-3; Franklin et al. 1946; Spedding, 1954; Shumard, Bolin \& Eveleth, 1957). The presence of these parasites may thus affect the nutrition of the host. Obviously a given effect of worm infestation on the growth rate of the lamb must be both more noticeable and more serious when the growth rate is low. Nutrition may thus affect the importance of damage due to parasites.

It is frequently assumed that a poor diet results in more helminths and that a well-fed animal will not be troubled with worms (Hunter, 1953), although Gibson (195 I) demonstrated that good nutrition alone cannot be relied upon to mitigate the effects of infestation with Trichostrongylus axei. It has been pointed out by Gordon (I957), however, that nutritional conditions in the field also affect the grazing habits of herbivores and that the provision of food supplements may reduce the intake of both grass and the infective larvae on it.

Within the sheep industry, it is probably in the production of fat lamb that worm infestation is of greatest consequence. Some lambs receive supplementary solid food and it is commonly observed that it reduces the amount they graze. For the vast majority of lambs, liquid milk is a major constituent of the diet: this paper examines the effect of milk intake on the opportunity of the lamb to acquire a serious worm burden. 


\section{Effect of milk intake on the growth rate of lambs}

Milk intake and growth rate are highly correlated for the first 4-6 weeks of the lamb's life (Wallace, 1948) and, in general, single lambs grow faster than twins and twins faster than triplets (Hammond, 1932; Large, 1959). Although ewes with twins may produce more milk than ewes with singles (Barnicoat, Logan \& Grant, 1949a,b; Alexander \& Davies, 1959), they do not produce enough to provide each twin with as much milk as a single lamb normally receives. Under conditions of food shortage (e.g. at very high stocking rates) ewes are able, to some extent, to maintain milk yield at the expense of body reserves, but, when milk yield is reduced, twins are more markedly affected than single lambs. Nutritional conditions have to be very poor to reduce the growth rate of singles to that normal for twins (Spedding, Brown $\&$ Large, I960). If, however, twin lambs receive as much milk as singles their growth rate approximates to that of singles (Wallace, 1948).

Thus milk intake has a dominant effect on growth rate in lambs. In a fat-lamb enterprise, lambs are sent for slaughter, as finished products, within a certain weight range. The lower the growth rate, therefore, the longer the lamb remains on the farm. Thus lambs that receive most milk generally (a) take a shorter time to fatten, (b) are sold directly off the ewe, without a separate period after weaning, (c) are at pasture for a shorter time and (d) are slaughtered relatively early in the season. Inevitably, they consume a smaller total quantity of herbage than lambs that receive less milk. Thus they have a reduced opportunity to acquire parasites by grazing.

\section{Effect of 'milk' intake on intake of solid food}

During artificial rearing of lambs it has been observed that little solid food is consumed when high levels of liquid milk substitute are given and that solid-food intake rises sharply during weaning (Large, 1959; Cunningham, Edwards \& Simpson, 196r; Spedding, Large \& Brown, I961).

In 1959 and 1960 , a total of six groups, each containing six Dorset Horn lambs, were reared from birth on the following three feeding regimes:

Group I Milk substitute to appetite four times a day; weaning during the 6th week

Group 2 A daily ration of 2 pints/head; weaning during the 6th week

Groups $3^{-6}$ Replicates receiving a daily ration of 2 pints/head; weaning during the $5^{\text {th }}$ and 6 th weeks

A pelleted, proprietary concentrate (analysis given as $16.4 \%$ protein $(\mathrm{N} \times 6.25)$, $3.2 \%$ oil, $6 \cdot 4 \%$ fibre) was available ad lib. to all groups at all times; the total consumption by each group was recorded daily. The milk substitute was prepared by adding $\mathrm{I} \frac{1}{2} \mathrm{lb}$ full-cream dried milk to $\mathrm{I}$ gal warm water, which gave a liquid with $87.4 \%$ water, $12.6 \%$ total solids, $3.5 \%$ fat, $3.5 \%$ protein $(\mathrm{N} \times 6 \cdot 25), 4.8 \%$ lactose and $0.8 \%$ ash. (The composition of ewe's milk was given by Brody (1945) as $83.1 \%$ water, $16.9 \%$ total solids, $6.1 \%$ fat, $5.5 \%$ protein, $4.5 \%$ lactose and $0.8 \%$ ash.) $22($ I) 4 
Vitamins $A$ and $D$ were added to the milk powder at the daily rate of 30 i.u. vitamin $\mathrm{D}_{2}$ and $\mathrm{I} 20 \mathrm{i}$.u. vitamin $\mathrm{A} / \mathrm{lamb}$.

For each of these groups there was a significant, negative relationship between intake of concentrates per unit live weight and milk substitute intake per unit live weight (Table I).

Table I. Regression $(y=a+b x)$ for groups of six lambs of concentrate intake $(y)$ on 'milk' intake $(x), y$ and $x$ being expressed as $g$ dry matter/kg live weight

\begin{tabular}{|c|c|c|c|c|}
\hline Group $\uparrow$ & a & $b$ & $\mathrm{SE}$ of $\mathrm{b}$ & r \\
\hline I & 3.0 & -0.05 & \pm 0.008 & $-0.964^{* *}$ \\
\hline 2 & $54 \cdot \mathrm{I}$ & $-2 \cdot 48$ & \pm 0.384 & $-0.966^{* *}$ \\
\hline 3 & $52 \cdot 2$ & $-\mathrm{I} \cdot 82$ & \pm 0.557 & $-0.883^{*}$ \\
\hline 4 & $55 \cdot 0$ & $-2 \cdot 13$ & $\pm 0.35 \mathrm{I}$ & $-0.950^{* * *}$ \\
\hline 5 & $54 \cdot 2$ & $-2 \cdot 35$ & \pm 0.447 & $-0.950^{*}$ \\
\hline 6 & 50.9 & $-I \cdot 76$ & \pm 0.533 & $-0.886^{*}$ \\
\hline \multicolumn{5}{|c|}{$\begin{aligned} * P<0.05 \\
* * P<0.01 \\
+ \text { See p. } 33\end{aligned}$} \\
\hline
\end{tabular}

In interpreting these relationships several important features of these experiments should be emphasized. First, the values for intake were the group means for I day (that on which the lambs were weighed) at weekly intervals. Secondly, changes in intake expressed per unit weight may be due either to alterations in absolute intake or to changes in live weight. Thirdly, the quantitative relationships might be expected to vary with the diet used. Finally, the results were for a limited age range (2-6 weeks); the relationship might be quite different at an age when the lamb is unable to consume appreciable quantities of solid food (which may possibly apply only to the Ist week of life). Intakes were expressed per unit body-weight since there was clearly a relationship between total dry-matter intake and body-weight (Fig. I).

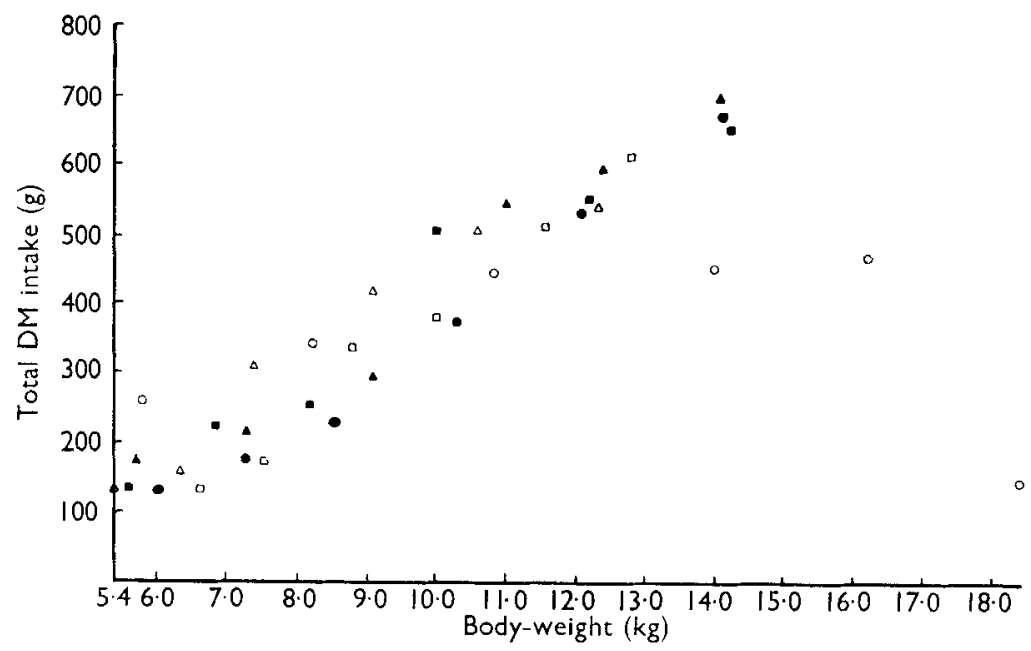

Fig. I. Relationship between body-weight of the lamb and intake of 'milk' and solid food. $O, \Theta, \Delta, \Delta$ $\square, \boldsymbol{D}$, groups $\mathrm{r}-6$ respectively (see p. 33 ). 
All the values for groups I-6 are shown in the figure; separate regression equations for each group are given in Table 2. The total dry matter intake was the sum of the 'milk' and solid intakes: since the milk substitute was deliberately rationed and

Table 2. Regression $(y=a+b x)$ for groups of six lambs of dry-matter intake $(y)$, expressed in $\mathrm{g}$, on live weight $(x)$, expressed in $\mathrm{kg}$

$\begin{array}{cc}\text { Group } & \text { a } \\ I & +370 \\ 2 & -316 \\ 3 & -207 \\ 4 & -254 \\ 5 & -386 \\ 6 & -200\end{array}$

$\begin{array}{cc}\mathrm{b} & \text { sE of } b \\ -\mathrm{I} \cdot 3 & \pm \mathrm{I} 3.7 \\ 68.9 & \pm 4.45 \\ 65.0 & \pm 7.45 \\ 67.9 & \pm 6.77 \\ 78.0 & \pm 4.64 \\ 62 . \mathrm{I} & \pm 7.19 \\ * * * 0.00 \mathrm{I}\end{array}$

NS, not significant.

only the solid offered ad lib., it is not possible to be certain that maximum voluntary intake of dry matter was achieved at all times. The three points (shown as open circles) on the lower right-hand side of Fig. I represent the intakes of lambs in group I immediately after weaning from a high level of milk feeding.

\section{Effect of 'milk' intake on the intake of grass}

Since the nature of the solid food may affect these relationships, an experiment was carried out in $196 \mathrm{I}$ to test the hypothesis that grass intake is negatively related to 'milk' intake. Intakes were measured with lambs from 4 to 8 weeks old, an age at which the level of intake of both liquid and solid can be considerable.

The establishment of groups receiving different levels of 'milk' intake involves either the use of animals of different weights or drastic changes in 'milk' intake during rearing: the following design was therefore adopted. All twenty-seven lambs were removed from their mothers 2 days after birth, allocated at random to one of three groups (A, B, C) and all fed ad lib. on a milk substitute (a proprietary product with $16 \%$ oil, $26 \%$ protein and $0.25 \%$ fibre), mixed with water at I lb to the gal, until each lamb reached the level of intake predetermined for its group. These levels were:

$$
\begin{array}{ll}
\text { A } & 2 \frac{1}{2} \text { pints/day } \\
\text { B } & 3 \frac{1}{2} \text { pints/day } \\
\text { C } & 4 \frac{1}{2} \text { pints/day }
\end{array}
$$

In this way, three groups of lambs were established whose intakes had risen naturally to these levels, which they received in the requisite number of $\frac{1}{2}$ pint feeds spaced evenly between 7 a.m. and 7 p.m. All lambs were taking their predetermined quantities of 'milk' by the time they were 4 weeks old. From then on S.23 ryegrass (cold-stored in the manner described by Raymond, Harris \& Harker, I 953a,b) was freely available to all lambs and intakes were measured over 3 -day periods in the middle of each week. The (partial) chemical composition of the grass was $3.64 \%$ N, I $1 \cdot 7 \%$ ash, $15 \cdot 9 \%$ soluble carbohydrates and $30 \cdot 8 \%$ normal acid fibre, on a dry- 
matter basis. The lambs were individually penned and weighed at weekly intervals. After 2 weeks, when the lambs were 6 weeks old, they were redistributed between the three treatments $(\mathrm{A}, \mathrm{B}, \mathrm{C})$ in such a way that one-third of them remained at their previous level and one-third was changed to each of the other two levels. This change was made at random within each original group and provided all combinations of levels in the second period (of 2 weeks), during which intakes of grass were again measured. Again, within this experiment, total dry-matter intake was related to live weight (Fig. 2 and Table 3 ) and intakes of milk substitute and grass have therefore

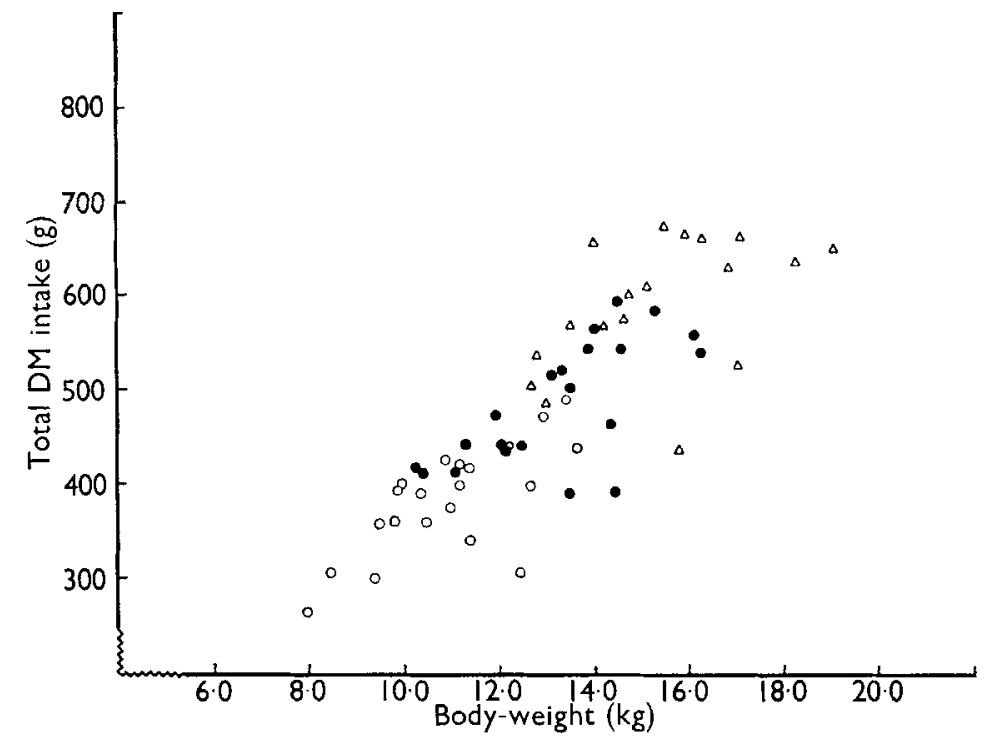

Fig. 2. Relationship between body-weight of the lamb and intake of 'milk' and grass. $0,4-5$ weeks old; - 5-6 weeks old; $\triangle, 6-7$ weeks old.

Table 3. Regression $(y=a+b x)$ for groups of six lambs of dry-matter intake $(y)$, expressed in $g$, on live weight $(x)$, expressed in $\mathrm{kg}$

$\begin{array}{crccc}\begin{array}{c}\text { Age of lambs } \\ \text { (weeks) }\end{array} & \mathrm{a} & \mathrm{b} & \text { SE of } \mathrm{b} & \mathrm{r} \\ 4-5 & 89 & 26.9 & \pm 5.83 & 0.718^{* * *} \\ 5-6 & \mathrm{I} 4 \mathrm{I} & 25.9 & \pm 6.42 & 0.679^{* * *} \\ 6-7 & 312 & 18.2 & \pm 8.47 & 0.474^{*} \\ & & & \\ & & P<0.05 . \\ * * * & P<0.001 .\end{array}$

been expressed per unit body-weight (Table 4). It has been suggested (Blaxter, Wainman \& Wilson, 196I) that the voluntary food intake of sheep varies approximately with metabolic body size, $\mathrm{W}^{0.73}$ (where $\mathrm{W}$ is the live weight), although this may not be relevant to rapidly growing lambs (Brody, 1945). Intakes were also expressed, therefore, per unit of metabolic size (Table 5). 
Table 4. Regression $(y=a+b x)$ for groups of six lambs of grass intake (y) on 'milk' intake $(x), y$ and $x$ being expressed as $g$ dry matter/kg live weight

$\begin{array}{ccccc}\begin{array}{c}\text { Age of lambs } \\ \text { (weeks) }\end{array} & \text { a } & \text { b } & \text { SE of b } & \text { r } \\ 4-5 & 32.0 & -0.80 & \pm 0.230 & -0.6 \mathrm{r}^{*} \\ 5-6 & 33.7 & -0.78 & \pm 0.204 & -0.66^{* *} \\ 6-7 & 39 \cdot 1 & -\mathrm{I} .02 & \pm 0.345 & -0.60^{* *} \\ & & * * 0.01 . & & \end{array}$

Table 5. Regression $(y=a+b x)$ for groups of six lambs of grass intake $(y)$ on 'milk' intake $(x), y$ and $x$ being expressed as $g$ dry matter $/(\text { kg live weight })^{0.73}$

$\begin{array}{ccccc}\begin{array}{c}\text { Age of lambs } \\ \text { (weeks) }\end{array} & \mathrm{a} & \mathrm{b} & \text { SE of } \mathrm{b} & \mathrm{r} \\ 4-5 & 62.6 & -0.85 & \pm 0.232 & -0.64^{* *} \\ 5-6 & 72.4 & -0.96 & \pm 0.213 & -0.72^{* * *} \\ 6-7 & 86.3 & -\mathrm{I} \cdot 22 & \pm 0.322 & -0.69^{* *} \\ & & * * 0.01 . & \\ & & & \\ & & & \end{array}$

Lambs receiving more 'milk' consumed less grass, whether intakes were expressed per unit of body-weight or of metabolic size. There was a significant, negative relationship in each of the three periods during which intakes were measured, both before and after the lambs had been redistributed between the three treatments.

When a lamb was changed to a lower 'milk' intake level it markedly increased its intake of grass; when it was given more 'milk' than previously its grass intake continued to increase with body growth, but at a much lower rate than that of a lamb whose 'milk' supply remained (absolutely) constant.

\section{Effect of milk intake on worm infestation}

The nematodes inhabiting the alimentary tract of the sheep do not multiply within the host: the establishment of adult worms in the tract thus depends on ingestion of infective larvae on the grass. Therefore, at any given number of larvae per unit weight of herbage, the number ingested by the lamb is proportional to the herbage intake. Since the latter is affected by intake of milk substitutes, intake of ewe's milk might also be expected to influence the number of infective larvae ingested. The situation is, however, immensely complicated in the field by non-uniformity (in space and time) of distribution of larvae on the grass and by the interactions of distribution of larvae intake and development of host immunity.

The clearest example of a field situation in which milk intakes are known to differ is that represented by single and twin lambs grazing the same pasture. Since there are also other differences between single and twin lambs, however, it is informative to include lambs born as twins but reared as singles. This was done in two experiments at Hurley (in 1959 and 1960 ), by removing one lamb of a twin pair at 2 or 4 weeks of age and leaving the other to enjoy an increased supply of milk. The results for 1959 are reported elsewhere (Spedding et al. 1960). In 1960, from lambing time (March) 


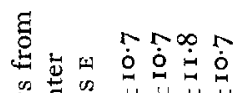

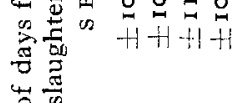

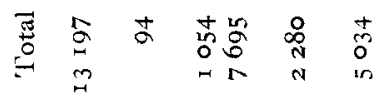

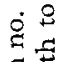

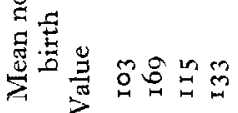

홍

离蒂

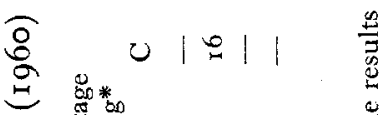

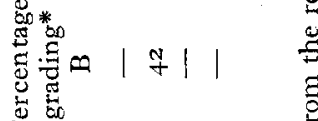

2 य움웧웅움

놀

胥

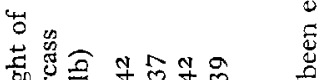

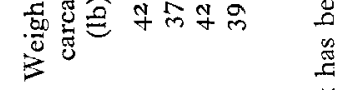

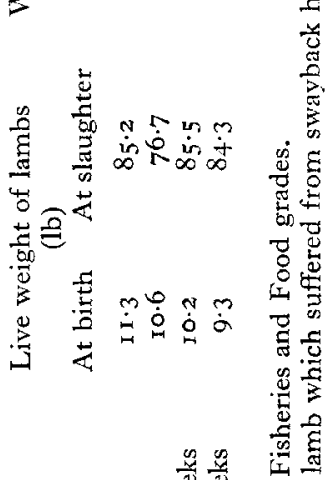

西

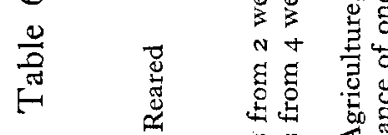

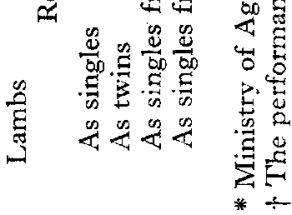

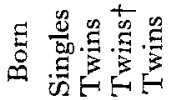

言

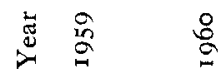


until the lambs reached marketable weights, four groups of six Halfbred ewes and their Suffolk cross ewe lambs were grazed together, set-stocked at six ewes/acre. The results are given in Table 6 . Single lambs (group I) grew faster than twins; the performance of twins reared as twins (group 2) was significantly poorer $(P<0.01)$ than that of twins reared as singles (groups 3 and 4 ) and than that groups I, 3 and $4(P<0.001)$, whether judged by the mean live-weight gain per day (which has limitations for non-linear growth) or by the mean number of days taken to reach slaughter weight. The performance of normal singles did not differ significantly from that of groups 3 and 4 and there was no significant difference between the latter groups.

Worms were counted and identified post mortem from all animals in 1960 and from ten lambs in 1959, by the methods described by the Grassland Research Institute (196I). The results are shown in Table 7 . In general, considerably more worms were recovered, in both years, from twins than from lambs reared as singles. The only exceptions were Ostertagia circumcincta in groups 3 and 4 and Nematodirus sp. in group I ( 1960$)$; the latter was due entirely to one single lamb which carried almost as many Nematodirus sp. as all the twins put together. An analysis of variance was carried out, for the predominant species, on values rounded to the nearest 10 and given a $\log$ transformation (for values +10 in order to remove zeros). For the first experiment (1959), the logarithmic means for Nematodirus sp. were: twins, $2 \cdot 73 \pm 0.380$ and singles, $\mathrm{I} \cdot 49 \pm 0.424$. For Trichostrongylus sp., none was found in any lamb reared as a single; the mean for twins was $3.00 \pm 0.656$. In the second experiment (I960) the means were: group I, I.44; group 2, 3.3 I; group 3, I.94; and group 4, 2.16 (SE for group 3, \pm 0.460 ; for groups I, 2 and $4, \pm 0.420$ ).

In 1960 , the longer the lambs remained as twins on the ewe the longer they took to fatten and the more worms they had post mortem. Thus, in this experiment, as in practice, milk intake was allowed to influence the length of time lambs remained on the pasture, by virtue of its influence on growth rate. For groups $1-4$, there was a highly significant correlation $\left(r=0.891^{* * *}\right)$ between the transformed values for the number of Trichostrongylus sp. post mortem and the number of days to slaughter. Values for individual animals were used for this analysis except that, throughout this paper, where twins and singles occur together, the means of twin pairs have been used, thus putting the analysis on a 'per ewe' basis.

\section{Discussion}

Some of the difficulties associated with the measurement of intake have been discussed by Blaxter et al. (I 96I). The achievement of maximal voluntary intake by the animals is influenced by the quantity of food offered and, in some instances, the method of feeding. To minimize these effects in the experiments described here, the total amount of solid feed offered to each lamb each day was always in excess of intake by a margin of at least $15 \%$. When pelleted feeds were offered they were continuously available; cold-stored grass was offered twice daily but each feed remained in a fresh condition for several hours. 
Under these conditions, intake of liquid milk substitute clearly influenced intake of solid foods, whether concentrate pellets or cold-stored ryegrass. The negative character of the relationship is of greater importance than the precise values associated with it, since these might be expected to vary with the quality of the feeds used.

Since intakes were related to body size, they have been expressed per unit of size: there was a negative relationship whether size was described in terms of live weight (W) or $\mathrm{W}^{0.73}$.

If a similar relationship applies to intakes of ewe's milk and grass, then the milk supply to the lamb could influence markedly the daily intake of infective larvae per unit body-weight. Whether, over the range of conditions possible in the field, a poor milk supply would necessarily result in a higher established worm burden and whether this worm burden would be more damaging to the host must depend on a number of factors, some of which are at present under investigation.

The results of the field experiments, however, clearly show that more worms were recovered post mortem from animals that received less milk. This finding is consistent with the hypothesis that milk intake influences worm infestation by affecting grass intake, although a direct effect of ewe's milk cannot be excluded. However, the influence of the milk supply need not necessarily be due to its effect on the daily intake of grass. It has been pointed out that milk supply influences growth rate and therefore the time required for fattening on pasture; an extension of this time normally increases total grass intake very markedly. In addition, it may expose the lamb, later in the season, to grass with a higher number of infective larvae on it.

Whichever of these possible mechanisms was the more important, it is clear that when lambs grazed together more milk resulted in fewer worms post mortem.

Thanks are due to Dr William Davies, Director, for facilities granted, to $\mathrm{Mr}$ I. A. N. Wilson, Miss M. C. Alexander and Miss E. Bomer for technical assistance and to Mr C. D. Kemp, Miss S. M. Green and Miss G. Fryd for statistical advice and analysis of results.

\section{REFERENCES}

Alexander, G. \& Davies, H. L. (1959). Aust. F. agric. Res. ro, 720.

Andrews, J. S., Kauffman, W. \& Davis, R. E. (1944). Amer. Y. vet. Res. 5, 22.

Barnicoat, C. R., Logan, A. G. \& Grant, A. I. (1949a). F. agric. Sci. 39, 44.

Barnicoat, C. R., Logan, A. G. \& Grant. A. I. (I949b). F. agric. Sci. 39, 237.

Blaxter, K. L., Wainman, F. W. \& Wilson, R. S. (I96r). Anim. Prod. 3, 5 I.

Brody, S. (1945). Bioenergetics and Growth. New York: Reinhold Publishing Corp.

Cunningham, J. M. M., Edwards, R. A. \& Simpson, M. E. (1961). Anim. Prod. 3, 105.

Franklin, M. C., Gordon, H. McL. \& Macgregor, C. H. (1946). F. Coun. sci. industr. Res. Aust. 19, 46. Gibson, T. E. (I95I). Personal communication.

Gibson, T. E. (1955). F. comp. Path. 65, 317.

Gordon, H. McL. (1950). Aust. vet. F. 26, 14, 46.

Gordon, H. McL. (r957). Advanc. vet. Sci. 3, 296.

Grassland Research Institute (1961). Bull. Bur. Past., Hurley, no. 45.

Hammond, J. (1932). Growth and Development of Mutton Quality in the Sheep. London: Oliver \& Boyd.

Hunter, G. C. (1953). Nutr. Abstr. Rev. 23, 705.

Kauzal, G. (1936). Aust. vet. F. 12, 107.

I.arge, R. V. (1959). Exp. Grassl. Res. Inst., Hurley, r2, I04.

Raymond, W. F., Harris, C. E. \& Harker, V. G. (1953a). Y. Brit. Grassl. Soc. 8, 301. 
Raymond, W. F., Harris, C. E. \& Harker, V. G. (1953b). F. Brit. Grassl. Soc. 8, 3 I 5.

Shumard, R. F., Bolin, D. W. \& Eveleth, D. F. (1957). Amer. F. vet. Res. r8, 330.

Spedding, C. R. W. (I953). F. Helminth. 27, 9.

Spedding, C. R. W. (1954). F. comp. Path. 64, 5.

Spedding, C. R. W. (1955). F. Brit. Grassl. Soc. ro, 35.

Spedding, C. R. W. \& Brown, T. H. (1957a). Ұ. agric. Sci. 48, 286.

Spedding, C. R. W. \& Brown, T. H. (1957b). F. agric. Sci. 49, 223.

Spedding, C. R. W. \& Brown, T. H. (1957c). F. agric. Sci. 49, 229

Spedding, C. R. W., Brown T. H. \& Large, R. V. (1960). Proc. int. Grassl. Congr. vilı. Reading, p. 718.

Spedding, C. R. W., Large, R. V. \& Brown, T. H. (1961). Vet. Rec. 73, 1428.

Stewart, J. (1932-3). Rep. Inst. Anim. Path. Univ. Camb. p. $5^{8 .}$

Taylor, E. L. (1942). Vet. Rec. 54, 377.

Taylor, E. L. (1953). F. R. agric. Soc. 14, 153.

Wallace, L. R. (1948). F. agric. Sci. 38, 93, 243, 367 .

\section{The effect of nutrition on the growth of Fasciola hepatica in its snail host}

By S. B. Kendall and C. B. Ollerenshaw, Ministry of Agriculture, Fisheries and Food, Central Veterinary Laboratory, New Haw, Weybridge, Surrey

Ever since the time of Thomas (1883) it has been accepted that the snail Limnaea truncatula plays an essential role in the epidemiology of fascioliasis. Thomas, whose investigations had been prompted by catastrophic losses of sheep in Britain during the years $1879-80$, commented on the enormous numbers of snails that could at times be found, and it has been commonly assumed that there is a direct relationship between the numbers of the vector and the intensity of infection reaching the definitive host. Factors other than the size of the snail population are, however, involved.

\section{Field studies}

At Weybridge, during the course of work designed to improve methods of control of fascioliasis in Britain, population studies on a number of habitats of L. truncatula have been combined with observations on the rate of infection with Fasciola hepatica. The results of two such studies, one on a 'flush' habitat (see Ollerenshaw, I958) on a hill farm in Scotland and the other on a shallow ditch habitat on a lowland farm in Wales are here reported.

On the hill farm in Scotland moisture conditions favourable to the snail were maintained over the restricted area of the habitat throughout the period of observation and on the few occasions when the population was sampled large numbers of small snails were found. In Fig. I the histograms show the size structure of the population. The forms of the histograms for May and December 1953 were repeated in the following year (Fig. I). Infected snails were found in each of the four collections. On this occasion the percentage of infected snails was small so that there may be some doubt about the validity of the observation; nevertheless it does appear that there are greater variations in the sizes of the parasite populations than in those of the snail populations. Certainly there is no evidence of a direct relationship between the numbers of snails and the numbers of parasites. 